\title{
Blood lead concentrations in free-ranging Nile crocodiles (Crocodylus niloticus) from South Africa
}

\author{
Jonathan K. Warner ${ }^{1,}{ }^{*}$, Xander Combrink ${ }^{1}$, Jan G. Myburgh ${ }^{2}$ and Colleen T. Downs ${ }^{1}$ \\ 1. School of Life Sciences, University of KwaZulu-Natal, Scottsville, Pietermaritzburg 3209, South Africa \\ 2. Department of Paraclinical Sciences, Faculty of Veterinary Science, University of Pretoria, Onderstepoort \\ 0110, South Africa
}

*Correspondence author: Jonathan K. Warner, email: jonathan.k.warner@gmail.com

\begin{abstract}
Generally crocodilians have received little attention with regard to the effects of lead toxicity despite their trophic status as apex, generalist predators that utilize both aquatic and terrestrial habitats, thereby exposing them to a potentially wide range of environmental contaminants. During July-October 2010 we collected whole blood from 34 sub-adult and adult free-ranging Nile crocodiles (Crocodylus niloticus) from three separate populations in northeastern South Africa in order to analyze their blood lead concentrations (BPb). Concentrations ranged from below detectability ( $<3 \mu \mathrm{g} / \mathrm{dL}, \mathrm{n}=8)$ to $960 \mu \mathrm{g} / \mathrm{dL}$ for an adult male at the Lake St Lucia Estuary. Blood lead concentrations averaged $8.15 \mu \mathrm{g} / \mathrm{dL}$ (SD = 7.47) for females and $98.10 \mu \mathrm{g} / \mathrm{dL}(\mathrm{SD}=217.42)$ for males. Eighteen individuals $(53 \%)$ had elevated BPbs ( $\geq 10 \mu \mathrm{g} / \mathrm{dL}$ ). We assessed 12 general linear models using Akaike's Information Criterion (AIC) and found no significant statistical effects among the parameters of sex, crocodile size and population sampled. On average, crocodiles had higher BPbs at Lake St Lucia than at Ndumo Game Reserve or Kosi Bay, which we attribute to lead sinker ingestion during normal gastrolith acquisition. No clinical effects of lead toxicosis were observed in these crocodiles, even though the highest concentration $(960 \mu \mathrm{g} / \mathrm{dL})$ we report represents the most elevated $\mathrm{BPb}$ recorded to date for a free-ranging vertebrate. Although we suggest adult Nile crocodiles are likely tolerant of elevated $\mathrm{Pb}$ body burdens, experimental studies on other crocodilian species suggest the BPb levels reported here may have harmful or fatal effects to egg development and hatchling health. In light of recent Nile crocodile nesting declines in South Africa we urge further BPb monitoring and ecotoxicology research on reproductive females and embryos.
\end{abstract}

Keywords: Crocodile, Crocodylus, Heavy metal, Lead, Ecotoxicology, South Africa

\section{Introduction}

Lead $(\mathrm{Pb})$ is an inert heavy metal that is ubiquitous in the environment but has no known physiological or metabolic benefit to animals (Buekers et al. 2009). Acute and chronic cases of $\mathrm{Pb}$ exposure can be fatal or lead to disorders of the nervous, gastrointestinal, reproductive, and circulatory systems. The epidemiology of $\mathrm{Pb}$ poisoning and toxicokinetics of $\mathrm{Pb}$ circulation and sequestration in analogous tissues and organs among different species, 
however, are poorly understood (Fisher et al. 2006; Sparling et al. 2010). Although many environmental contaminants are accumulated within organisms through inhalation or permeation of the integument, $\mathrm{Pb}$ intoxication in wildlife occurs primarily through oral ingestion (Nadjafzadeh et al. 2013). After humans, most of the literature that addresses $\mathrm{Pb}$ as a metabolic poison focuses on Aves. The link between birds spanning a wide-variety of taxa and the ingestion of $\mathrm{Pb}$ is well documented (Fisher et al. 2006; Lambertucci et al. 2011; Naidoo et al. 2012; and references therein). Recent research has established clinical concentration levels in bird populations due to the direct and indirect ingestion of $\mathrm{Pb}$ shot and fishing tackle, which has prompted several countries to ban recreationally-used $\mathrm{Pb}$ based bullets and sinkers (Thomas 1997).

Compared with birds and mammals, ectothermic organisms like reptiles have received relatively little research attention with regard to the potential and actual effects of $\mathrm{Pb}$ toxicity caused by polluted environments. Such attention is warranted given that many squamate, testudine and crocodilian species partition their lifespans between aquatic and terrestrial habitats, occupy different trophic positions dependent on size or age, and employ multiple foraging strategies. Their behavior potentially exposes them to a wide range of environmental contaminants due to their complex life histories (Sparling et al. 2010).

As long-lived vertebrates and apex predators, crocodilians (gharials, caimans, alligators and crocodiles) in particular are excellent study subjects for understanding environmental and ecosystem health (Campbell 2003; Milnes and Guillette 2008). Multiple studies (Twinning et al. 1999; Jeffree et al. 2001; Rainwater et al. 2007) report background or elevated Pb concentrations in the flesh and osteoderms of several species in the wild, but information about the clinical symptoms and reproductive effects of $\mathrm{Pb}$ toxicosis is mainly limited to studies on captive crocodilians fed meat contaminated with $\mathrm{Pb}$ shot (Camus et al. 1998; Hammerton et al. 2003; Lance et al. 2006). One experimental study of four juvenile saltwater crocodiles (Crocodylus porosus) dosed with $\mathrm{Pb}$ shot suggested a half-life for $\mathrm{Pb}$ in blood of about 3.4 days (Hammerton et al. 2003). Quantifying Pb body burdens and making relevant comparisons between tissues and species has been hindered by various nonstandardized documentations of $\mathrm{Pb}$ concentrations using a variety of ratios (e.g. $\mu \mathrm{g} / \mathrm{g}, \mathrm{ng} / \mathrm{g}$, $\mathrm{ppm}$ ) reported in wet, dry or unspecified masses. Clinical studies of $\mathrm{Pb}$ intoxication in living humans, domestic animals and wildlife are standardly reported in $\mu \mathrm{g} / \mathrm{dL}$ from whole blood samples because $\mathrm{Pb}$ is mainly present in erythrocyte (red blood) cells.

In Africa, Almi et al. (2005) found hepatic Pb concentrations ranging from 0.71 to $17 \mu \mathrm{g} / \mathrm{g}$ and renal concentrations ranging from 0.07 to $2.2 \mu \mathrm{g} / \mathrm{g}$ from tissue samples harvested from nine Nile crocodiles (Crocodylus niloticus) in the Kafue and Luangwa Rivers in Zambia.

Swanepoel et al. (2000) noted comparable values in $\mathrm{Pb}$ concentrations from kidney and liver tissues collected from 15 Nile crocodiles in the Kruger National Park, South Africa, with the highest concentration $(19.85 \mu \mathrm{g} / \mathrm{g})$ occurring in the liver of an individual from the Olifants River. The respective river systems in the two studies are associated with mining operations and metal pollution along sections of their reaches. Potential biomagnification of anthropogenically introduced $\mathrm{Pb}$ through the food chain was suggested by the authors as the cause of elevated $\mathrm{Pb}$ levels in the crocodile tissues. For Nile crocodiles the background, subclinical and clinical $\mathrm{Pb}$ concentrations in blood have not been recorded and $\mathrm{Pb}$ blood kinetics are not understood. 
In 2009-2010 approximately a dozen severely emaciated Nile crocodiles were observed during field capture excursions and aerial and boat surveys at Lake St Lucia in the iSimangaliso Wetland Park (a UNESCO World Heritage Site), South Africa. Emaciated Nile crocodiles had protruding scapulae and spinal columns, and open abscesses where the anterior gastralia and sternum contact the substrate (indicating long periods of immobility) (Warner et al. unpublished data). Two individuals in very poor condition were euthanized and elevated $\mathrm{Pb}$ concentrations were found in liver tissue and blood plasma in addition to fishing sinkers found in the stomachs (Warner et al. unpublished data). Consequently a program of Pb surveillance in the whole blood of living Nile crocodiles at three populations in northeastern South Africa was initiated. We predicted elevated $\mathrm{Pb}$ concentrations in Nile crocodiles at Lake St Lucia compared with the other two populations. We examine through statistical modelling if BPb concentration is related to sex or body size, and discuss the ramifications of $\mathrm{Pb}$ ingestion and tolerance as it potentially relates to reproduction and nesting.

\section{Methods}

\section{Study animals}

The Nile crocodile is an apex predator widespread throughout many aquatic ecosystems in sub-Saharan Africa. In South Africa the species is IUCN red-listed as Vulnerable (Marais 2014), with remaining viable populations restricted to protected areas and waterbodies under some degree of conservation management. There are recent declines in major populations (Kruger National Park, Flag Boshielo Dam, Loskop Dam, Ndumo Game Reserve, iSimangaliso Wetland Park) due to poaching and indiscriminate killing (Calverley and Downs 2014a), loss of nesting habitat (Combrink et al. 2011) and environmental degradation (Botha et al. 2011; Ferreira and Pienaar 2011). These trends are concerning not only with regard to the long-term persistence of the species but also for the ecological integrity and environmental health of aquatic ecosystems in northeastern South Africa (Combrink et al. 2013).

\section{Sampling sites}

We collected blood samples from individuals at three allopatric Nile crocodile populations in the province of KwaZulu-Natal, South Africa. The 10,000 ha Ndumo Game Reserve (MGRS 36JVR3036825394) occurs inland at the western edge of the Mozambique Coastal Plain. The Usuthu and Phongola Rivers form the northern and eastern boundaries of the reserve, respectively. During the rainy season (Nov-Mar) up to $40 \%$ of the reserve may be inundated, including 12 permanent and semi-permanent pans that are critical habitats yearround for the approximately 900 crocodiles in the area (Calverley and Downs 2014b). Anthropogenic pressures and habitat loss have largely extirpated the species from the greater floodplain outside the reserve (Calverley and Downs 2014a).

East of Ndumo Game Reserve (50 km) is Kosi Bay (MGRS 36JVR8210609928) which sits adjacent to the Indian Ocean as the northernmost component of the 328,000 ha iSimangaliso Wetland Park, a UNESCO World Heritage Site. The ecosystem consists of an estuary mouth that flows into a linear series of four lakes on a salinity gradient 
interconnected by narrow channels. Legal mass-scale fishtrapping by local Tsonga people and illegal gillnets are significant threats to Nile crocodiles (Kyle 1999) and aerial and boat spotlight surveys show Kosi Bay currently harbors $<20$ crocodiles (Warner et al. unpublished data).

South of Kosi Bay (down the coast $120 \mathrm{~km}$ ), within the iSimangaliso Wetland Park, is the St Lucia estuarine system (MGRS 36JVP4779196119) known as Lake St Lucia. At $67 \mathrm{~km}$ in total length, the main lake basin ( $6 \mathrm{~km}$ wide at capacity) is connected to the ocean via a $27 \mathrm{~km}$ long "Narrows" channel. Lake St Lucia is a highly dynamic environment over space and time with cyclical, but often unpredictable annual fluctuations between drought and high rainfall (Stretch et al. 2013). Inputs of freshwater from five feeder rivers and seeps on the eastern lake edge are critical components in the feeding, nesting and movement ecology of Nile crocodiles ( 1000 individuals) at Lake St Lucia (Combrink 2014). Due to a decade-long drought, at the time of our sampling in 2010 the estuary mouth was closed, there were limited freshwater inputs, and significant sections of the lake were exposed due to evaporation.

Recreational (line and tackle) fishing is permitted at Kosi Bay but prohibited at Ndumo Game Reserve. Lake St Lucia historically and up to present is a major regional fishing destination with most angling activities confined to the estuary mouth area and southern portion of the Narrows.

\section{Crocodile capture and blood collection}

We captured Nile crocodiles from boats and/or on foot during both nocturnal and diurnal hours dependent on environmental conditions and researcher accessibility to crocodile habitat under permit from Ezemvelo KZN Wildlife and ethics permission from the University of KwaZulu-Natal. Crocodiles were secured using a variety of noosing snares, ropes, hooks and traps according to standard operating procedure (Combrink et al. 2012). Once an individual was safely restrained, blood was collected immediately before body measurements and tagging activities were undertaken. Blood for $\mathrm{Pb}$ analysis was drawn from the post-occipital spinal venous sinus using a $20 \mathrm{ml}$ syringe with a $18 \mathrm{G}$ needle (Myburgh et al. 2014). Either a 1.5" hypodermic needle or 3.5" spinal needle (Terumo Corporation, Tokyo, Japan) was used depending on the body size and/or neck fat of individual crocodiles. The blood samples were deposited into spray-coated $K^{2}$ EDTA $6 \mathrm{ml}$ plastic tubes (BD Vacutainer ${ }^{\circ}$ ), slowly inverted to mix contents, and refrigerated whole (not centrifuged) at $1.6^{\circ} \mathrm{C}$ until delivered for analysis $1-7$ days post-collection. We determined sex for each crocodile by inserting a finger into the cloaca and palpating for the presence or absence of the penis (Brazaitis 1968). Snout-to-vent length (SVL) was measured dorsally as the distance from the tip of the snout to the posterior end of the cloacal opening for each individual. For crocodilians, SVL is the standard measurement of body length because their tails can be partially missing, damaged or deformed. As part of an ancillary study of $C$. niloticus demographics and morphology a suite of ten additional morphometric and body condition measurements were also collected (Warner 2015). 


\section{Clinical analyses}

Nile crocodile blood samples were analyzed for their $\mathrm{Pb}$ concentration (BPb) by Ampath Laboratories, The Bay Hospital, Richards Bay, South Africa. The determination of BPb was performed using a Graphite Furnace Atomic Absorption Spectrometer (GFAAS, Varian AAZ 220). Standard blood processing and AAS operational parameters were observed according to Zinterhofer et al. (1971) and Perkin-Elmer (1996). Blood aliquot analysis was performed twice for each sample to ensure BPb validity. Detection limit of BPb for GFAAS was $3 \mu \mathrm{g} / \mathrm{dL}$. As such, some samples that registered as $3 \mu \mathrm{g} / \mathrm{dL}$ (Table 1) may have in fact represented BPbs slightly less than this value, but were demarcated as $3 \mu \mathrm{g} / \mathrm{dL}$ for statistical modelling.

Table 1. Whole blood lead concentrations from wild Nile crocodiles in KwaZulu-Natal, South Africa

\begin{tabular}{|c|c|c|c|c|c|c|}
\hline Croc ID & $\begin{array}{l}\text { Blood Pb conc. } \\
(\mu \mathrm{g} / \mathrm{dL})\end{array}$ & Population & Locality & Date (2010) & SVL (mm) & Sex \\
\hline 3 & 3 & KB & SC & $07-02$ & 495 & $\mathrm{~F}$ \\
\hline 4 & 10 & KB & SC & $07-02$ & 1060 & M \\
\hline 6 & 8 & KB & SC & $07-02$ & 898 & M \\
\hline 7 & 3 & KB & $4 \mathrm{~L}$ & $07-03$ & 693 & $\mathrm{~F}$ \\
\hline 8 & 8 & KB & $4 \mathrm{~L}$ & $07-03$ & 681 & M \\
\hline 86 & 8 & NGR & IP & $06-21$ & 1760 & $\mathrm{~F}$ \\
\hline 87 & 16 & NGR & IP & $06-21$ & 996 & $M$ \\
\hline 88 & 3 & NGR & IP & $06-21$ & 758 & $\mathrm{~F}$ \\
\hline 90 & 3 & NGR & IP & $06-23$ & 924 & M \\
\hline 91 & 10 & NGR & IP & $06-23$ & 1344 & $M$ \\
\hline 92 & 6 & NGR & IP & $06-21$ & 916 & $\mathrm{~F}$ \\
\hline 94 & 3 & NGR & IP & $06-23$ & 1384 & $\mathrm{~F}$ \\
\hline 95 & 3 & NGR & IP & $06-23$ & 1150 & $\mathrm{~F}$ \\
\hline 96 & 6 & NGR & IP & $06-24$ & 1964 & $M$ \\
\hline 98 & 3 & NGR & IP & $06-24$ & 1030 & M \\
\hline 99 & 18 & NGR & IP & $06-24$ & 1334 & M \\
\hline 111 & 960 & STL & NC & $10-22$ & 1527 & $M$ \\
\hline 504 & 20 & STL & LBS & 06-09 & 2310 & $M$ \\
\hline 505 & 4 & STL & LBS & 06-19 & 727 & $M$ \\
\hline 506 & 3 & STL & LBS & 06-19 & 764 & $\mathrm{~F}$ \\
\hline 508 & 26 & STL & NS & $07-21$ & 1810 & $\mathrm{M}$ \\
\hline 509 & 344 & STL & NC & $08-21$ & 1678 & $M$ \\
\hline 510 & 18 & STL & NC & $10-22$ & 1642 & $\mathrm{~F}$ \\
\hline 511 & 8 & STL & PC & $10-07$ & 863 & $\mathrm{~F}$ \\
\hline 512 & 32 & STL & NS & $10-08$ & 1818 & $M$ \\
\hline 513 & 16 & STL & NS & $10-08$ & 1684 & $M$ \\
\hline 514 & 8 & STL & $\mathrm{MR}$ & $10-23$ & 1392 & $\mathrm{~F}$ \\
\hline 515 & 12 & STL & $\mathrm{MR}$ & $10-23$ & 1610 & $\mathrm{~F}$ \\
\hline 516 & 280 & STL & $\mathrm{MR}$ & $10-25$ & 1626 & $M$ \\
\hline 517 & 28 & STL & $M R$ & $10-25$ & 1658 & $\mathrm{~F}$ \\
\hline 518 & 64 & STL & $\mathrm{MR}$ & $10-26$ & 1444 & $M$ \\
\hline 519 & 42 & STL & $\mathrm{MR}$ & $10-26$ & 1474 & $M$ \\
\hline 520 & 126 & STL & $\mathrm{MR}$ & $10-27$ & 2122 & $M$ \\
\hline 521 & 64 & STL & $\mathrm{MR}$ & $10-29$ & 2188 & $M$ \\
\hline
\end{tabular}

KB Kosi Bay, NGR Ndumo Game Reserve, and the following from Lake St Lucia where STL St Lucia Estuary, SC Sihadla Channel, $4 L$ Fourth Lake, IP Inyamithi Pan, NC Narrows Channel, PC Potter's Channel, NS Nkazana Stream, MR Mphate River, SVL snout-to-vent length) 


\section{Statistical methods}

All analyses were performed using R version 2.12.1 (R Development Core Team 2011). Blood $\mathrm{Pb}$ concentration and $\mathrm{SVL}$ values were first z-transformed as to be on equivalent scales. We then assessed 12 General Linear Models using Akaike's Information Criterion (AIC), an information theoretic approach (Burnham and Anderson 2002) which is described as $A I C=-2(\log -$ likelihood $)+2 K$ where $\mathrm{K}$ is the number of estimated parameters included in the model (i.e., $\mathrm{SVL}+\mathrm{sex}+$ the intercept). The log-likelihood was generated from the statistical output and reflected the overall fit of the model (smaller values indicate worse fit). Because of our relative small sample size for each population, the second-order Akaike Information Criterion (AICC) was used where $n$ is the sample size AICC $=-2(\log -$ likelihood $)+2 K+2 K(K+1)(n-K-1)$

The 12 candidate set included a null model (intercept only), all main effects models (sex, SVL, population), all 2-way models with and without interactions, and a global model which included all main effects, all 2-way interactions and all 3-way interactions. If model support was low, we used model averaging on the $95 \%$ confidence set of models (Akaike Weights summing to 0.95$)$.

\section{Results}

During July-October 2010 we collected whole blood for Pb analysis from 34 subadult and adult Nile crocodiles (Kosi Bay: $n=5$, Ndumo Game Reserve: $n=11$, Lake St Lucia: $n=18$; Table 1). Concentrations ranged from below detectability $(<3 \mu \mathrm{g} / \mathrm{dL}, \mathrm{n}=8)$ to $960 \mu \mathrm{g} / \mathrm{dL}$ (croc no. 111, Lake St Lucia). For Lake St Lucia, 11 individuals had Pb blood concentrations $>20 \mu \mathrm{g} / \mathrm{dL}$ while Ndumo Game Reserve and Kosi Bay collectively had no sample $>18 \mu \mathrm{g} / \mathrm{dL}$ (Table 1). Blood Pb concentrations averaged $8.15 \mu \mathrm{g} / \mathrm{dL}(\mathrm{SD}=7.47$ ) for females and $98.10 \mu \mathrm{g} / \mathrm{dL}(\mathrm{SD}=217.42$ ) for males (also see boxplots with SEM in Fig. 1).

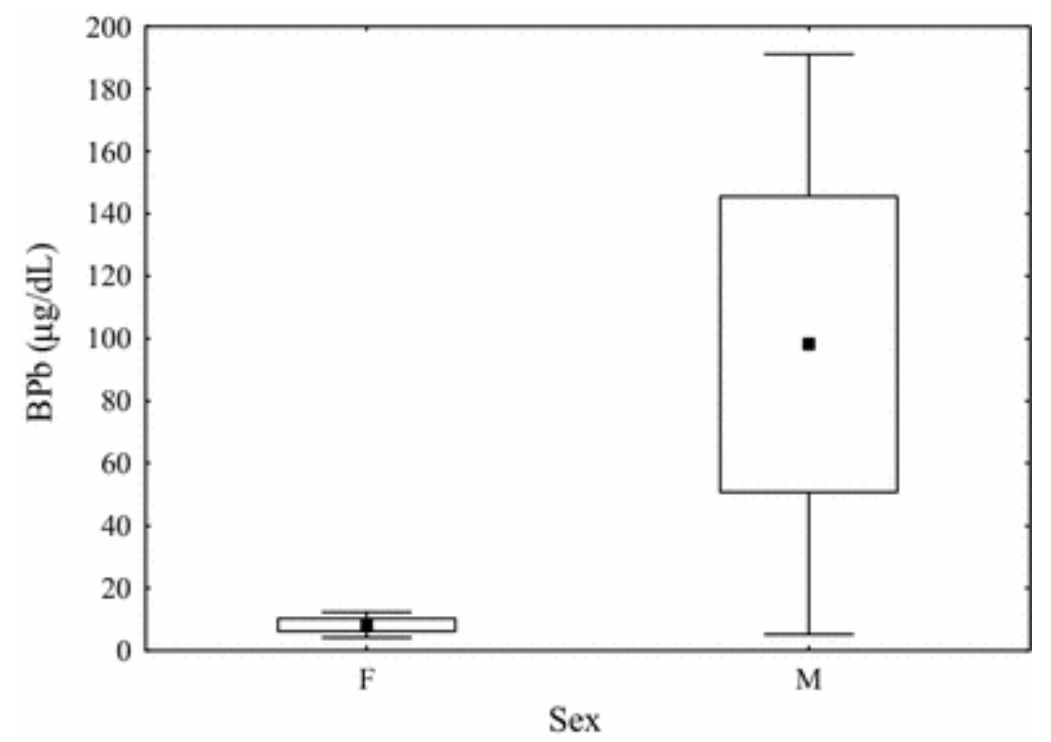

Fig. 1. For 34 Nile crocodiles sampled in South Africa mean lead concentration $(\mu \mathrm{g} / \mathrm{dL})$ in whole blood was higher for males (98.10) than females (8.15), but not statistically significant $(t=-1.48, d f=32, p=0.15)$. Boxes are mean $\pm \mathrm{SE}$, error bars are mean $\pm \mathrm{SE}(1.96)$ 
Multiple competing models showed that no single model explained a significant amount of the statistical variance (Table 2), and model averaging revealed that data slopes were not significantly different from zero for the $95 \%$ confidence set of models (Table 3). Statistical variance found for Nile crocodile BPb values among the three populations is presented in Fig. 2. The relationship between male and female crocodile size (SVL) and blood lead concentration is plotted in Fig. 3.

Table 2. Twelve models as determined by AIC for General Linear Model analysis of Nile crocodile whole blood lead concentration $(n=34$ ) sampled at 3 northeastern South African populations in 2010

\begin{tabular}{|cccccccc|}
\hline \hline Rank & Model & $\boldsymbol{K}$ & $\mathbf{- 2 L L}$ & AICc & $\Delta$ AICc & $\boldsymbol{w}_{\boldsymbol{i}}$ & $\Sigma \boldsymbol{w}_{\boldsymbol{i}}$ \\
\hline 1 & Null & 2 & -47.736 & 99.860 & 0.000 & 0.250 & 0.250 \\
2 & Sex & 3 & -46.608 & 100.015 & 0.155 & 0.232 & 0.482 \\
3 & zSVL & 3 & -47.003 & 100.806 & 0.946 & 0.156 & 0.638 \\
4 & $\mathrm{P}$ & 4 & -46.014 & 101.408 & 1.548 & 0.116 & 0.754 \\
5 & zSVL + Sex & 4 & -46.276 & 101.932 & 2.072 & 0.089 & 0.843 \\
6 & Sex + P & 5 & -45.063 & 102.270 & 2.410 & 0.075 & 0.918 \\
7 & zSVL + P & 5 & -45.953 & 104.048 & 4.188 & 0.031 & 0.949 \\
8 & zSVL + Sex & 5 & -46.177 & 104.497 & 4.637 & 0.025 & 0.973 \\
9 & Int & & & & & & 0.990 \\
10 & zSVL + P + Se & 6 & -45.058 & 105.227 & 5.367 & 0.017 & 0.999 \\
11 & Xex + P Int & 7 & -44.199 & 106.707 & 6.847 & 0.008 & 1.000 \\
12 & zSVL + P Int & 7 & -45.930 & 110.168 & 10.308 & 0.001 & 1.000 \\
\hline
\end{tabular}

$K$ number of parameters, $L L$ log-likelihood, $A I C C$ second-order Akaike Information Criterion, $w_{i}$ is the Akaike weight, and $\sum w_{i}$ is the cumulative sum of the Akaike weights. For the models, $z S V L$ z-transformed snout-tovent length and $P$ population

Table 3. Average parameters for the $95 \%$ confidence set of models determined by AIC for wild Nile crocodile whole blood lead analysis with all non-significant effects

\begin{tabular}{|cccccc|}
\hline \hline Parameter & Beta & SE & Lower C.I. & Upper C.I. & Significance \\
\hline (Intercept) & -0.200 & 0.351 & -0.889 & 0.489 & N.S. \\
zSVL & 0.158 & 0.204 & -0.242 & 0.559 & N.S. \\
LeadSexMale & 0.481 & 0.354 & -0.214 & 1.176 & N.S. \\
LeadPopNGR & 0.003 & 0.535 & -1.045 & 1.051 & N.S. \\
LeadPopSTL & 0.589 & 0.515 & -0.421 & 1.598 & N.S. \\
\hline
\end{tabular}




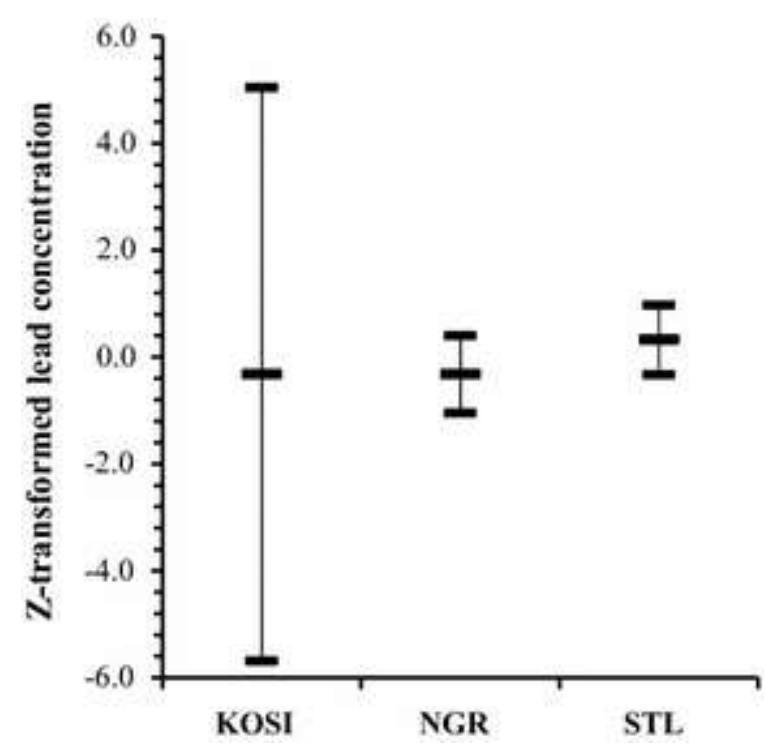

Fig. 2. Non-significant statistical effects were found for Nile crocodile blood lead concentration (BPb) values among three allopatric populations in KwaZulu-Natal, South Africa. KB Kosi Bay, NGR Ndumo Game Reserve, STL Lake St Lucia. Error bars are mean \pm SD

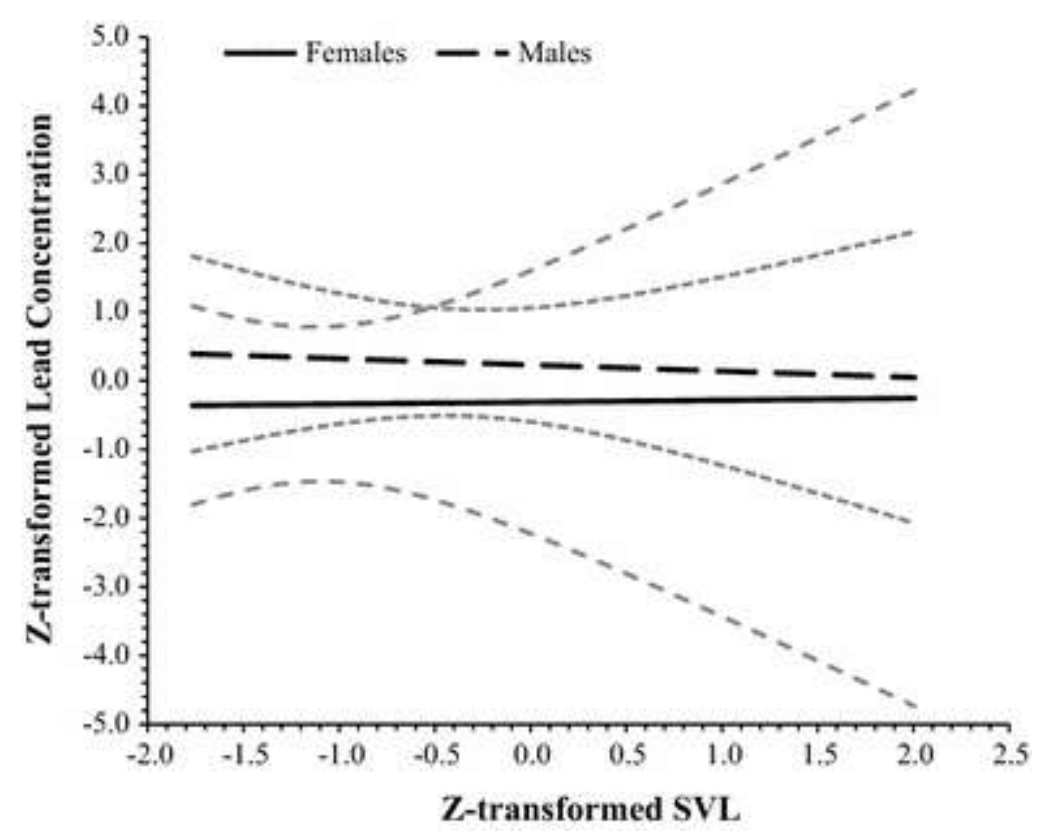

Fig. 3. Male and female wild Nile crocodile snout-to-vent length (SVL) (bold lines) plotted against their blood lead concentrations showed overlapping confidence intervals (dashed lines)

\section{Discussion}

Our study is the first to report whole blood $\mathrm{Pb}$ concentrations (BPb) for live free-ranging Nile crocodiles. We assessed 12 general linear models using Akaike's Information Criterion (AIC) and found no significant effects among the parameters of sex, crocodile size and population sampled. Given the robustness of the AIC analysis and our relative small sample size, the lack of significant statistical effects was not surprising despite $53 \%$ (18 individuals) of samples registering elevated $\mathrm{BPb}(\geq 10 \mu \mathrm{g} / \mathrm{dL})$. The extensive range of $\mathrm{BPbs}$ without quantitative clustering among groups hindered the selection of a successful model using 
AIC. The male crocodile from Lake St Lucia with a BPb of $960 \mu \mathrm{g} / \mathrm{dL}$ is to our knowledge the highest recorded $\mathrm{BPb}$ for a free-ranging vertebrate species. For clinical reference, in falconiformes and waterfowl BPb levels $>100 \mu \mathrm{g} / \mathrm{dL}$ are considered toxic (Franson 1996; Pain 1996), while concentrations greater than $60-80 \mu \mathrm{g} / \mathrm{dL}$ represent toxicosis in mammals (Ma 1996). The BPb threshold of concern for human children as set by the US Centers for Disease Control and Prevention is $5 \mu \mathrm{g} / \mathrm{dL}$.

We attribute the elevated levels observed at Lake St Lucia to the widespread and longstanding recreational use of $\mathrm{Pb}$ fishing sinkers (pers. obs.), albeit largely by process of elimination of other potential sources. The geology of the area consists of quaternary dune sands and sandy coastal sediment deposits and lacks mineral deposits containing $\mathrm{Pb}$ ore (Botha et al. 2013). As a World Heritage Site, hunting and recreational shooting are prohibited and there are no industrial or mining waste inputs into the estuary ecosystem. The major cause of sedimentation deposited by freshwater rivers is agricultural runoff from the numerous sugarcane fields in the greater coastal plain (Stretch et al. 2013).

Furthermore, during the course of this study from 2009 to 2014 all crocodiles $(n=8)$ examined that died of natural causes, incidental or intentional killing were found to have multiple fishing sinkers in their stomach cavities (Fig. 4). Unfortunately, the logistics of working in a remote location prohibited us from radiographing captured crocodiles for the presence of stomach $\mathrm{Pb}$.

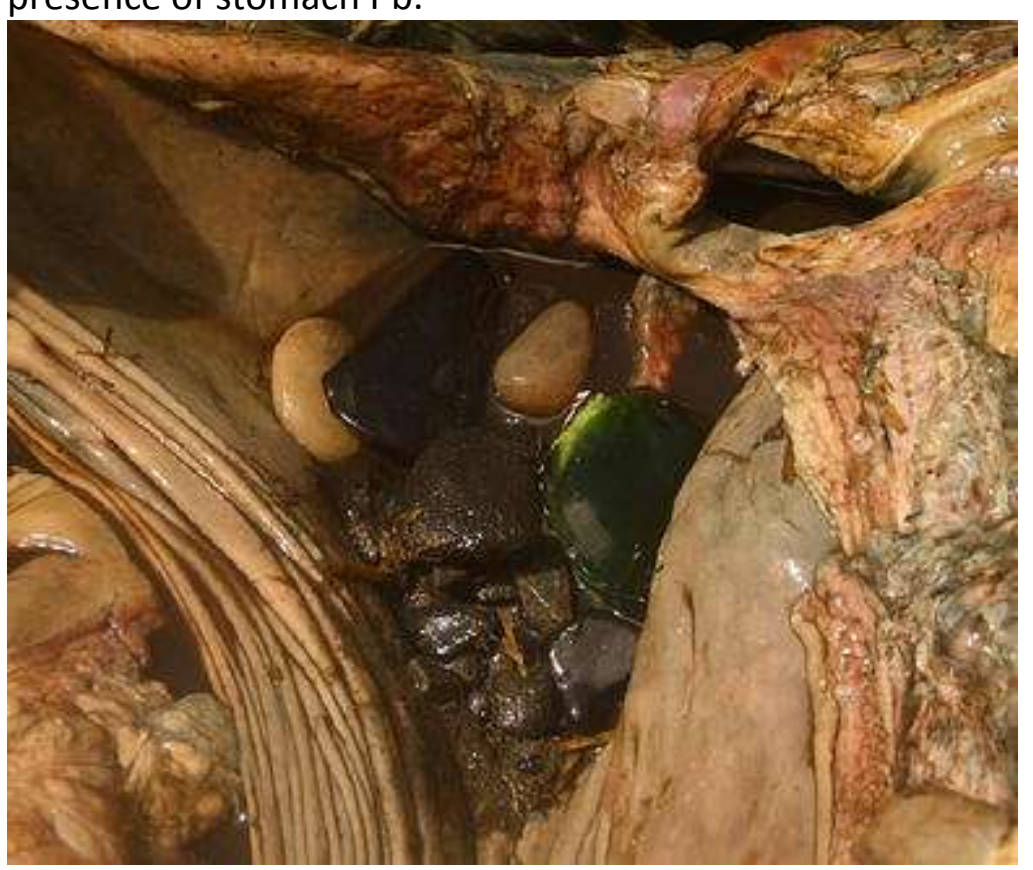

Fig. 4. Stomach contents from a large ( $4.1 \mathrm{~m}$ total length) adult male Nile crocodile from the Lake St Lucia Estuary, iSimangaliso Wetland Park, South Africa: four lead fishing sinkers, broken glass, a spark plug, assorted stone gastroliths (Combrink 2014)

While secondary ingestion of $\mathrm{Pb}$ fishing tackle through consumption of fish that contain sinkers cannot be ruled out, crocodiles are likely swallowing $\mathrm{Pb}$ sinkers through normal gastrolith acquisition and perhaps occasional theft of fishing bait. The function of crocodile gastroliths (stomach stones) is not fully known but they likely help serve as ballast and/or grind down food items (Wallace and Leslie 2008). The small crocodilian pylorus prevents gastroliths from passing into the duodenum and being excreted as waste (Chiasson 1962), 
but small metal fragments that are ingested but not absorbed may be eliminated through the feces (Xu et al. 2006). The rate of retention and erosion of $\mathrm{Pb}$ solids in the crocodilian gastrointestinal tract is not well understood. However it is clear that low stomach $\mathrm{pH}$ aids the dissolution of $\mathrm{Pb}$ (Hammerton et al. 2003), which after entering systemic circulation is carried by red blood cells and sequestered into organs (especially the kidney and liver), soft tissues, and ultimately bone, which bears $90 \%$ of the body burden (Hammerton et al. 2003; Grillitsch and Schiesari 2010).

In a controlled experiment where three captive juvenile saltwater crocodiles (Crocodylus porosus) were fed five $\mathrm{Pb}$ shot each (mean mass $377 \pm 17 \mathrm{mg}$ ) BPbs increased 10-20 fold during the first 7 days after exposure and attained steady-equilibrium after 20 days at 278$363 \mu \mathrm{g} / \mathrm{dL}$. A fourth juvenile fed ten Pb shot had an upper plateau BPb of $514 \pm 33 \mu \mathrm{g} / \mathrm{dL}$ at 85-140 days after exposure (Hammerton et al. 2003). If similar Pb blood kinetics hold for Nile crocodiles, the highly elevated BPbs (e.g. 126, 280, 344, $960 \mu \mathrm{g} / \mathrm{dL}$ ) we found in individuals at Lake St Lucia could reasonably be explained by either single or multiple events of $\mathrm{Pb}$ sinker ingestion in the weeks or months prior to capture. While our results show possible $\mathrm{Pb}$ intoxication we cannot adduce clinical significance. At time of capture none of the Nile crocodiles we sampled had any observable or quantifiable signs of physical attrition, deformation, or abnormal behaviour compared with other individuals captured and not sampled for BPb throughout the course of the study (Warner 2015). As part of concurrent ecological research, the individual with the highest $\mathrm{BPb}$ (no. 111; Table 1) was fitted with a GPS-GSM transmitter and exhibited normal movements within his home range for the duration of the study (Combrink 2014). Our findings therefore support the previous hypothesis of Cook et al. (1988) and Hammerton et al. (2003) that crocodilians likely possess a high degree of resistance to $\mathrm{Pb}$ toxicity. That notwithstanding, some of the BPbs reported in this study are concerning for a largely pristine, protected environment.

In light of recent nesting declines at STL (Combrink 2014), breeding females and embryos merit a more intensive research focus with regard to environmental contaminants, especially $\mathrm{Pb}$. Although adult $\mathrm{C}$. niloticus may be able to tolerate elevated $\mathrm{Pb}$ body burdens, there is evidence that female crocodilians shunt $\mathrm{Pb}$ into developing embryos, leading to eggshell thinning, deformities or death even at low concentrations (Heinz et al. 1991; Manolis et al. 2002; Lance et al. 2006). There is one recorded instance of elevated Pb concentrations in Nile crocodile eggs but the cause and health of the hatchlings is unknown (Phelps et al. 1986). The sequestration of contaminants into gonadal tissues and the significance of intergenerational transfer in reducing maternal body burden require further study in crocodilians. The deleterious effects of $\mathrm{Pb}$ on reproductive success, egg production, eggshell thinning, and embryo health has been more extensively documented in Aves (Fisher et al. 2006 and refs. therein, Watson et al. 2009), and the toxicokinetic processes between mother and oocyte are likely similar among crocodiles (Grillitsch and Schiesari 2010).

Sex related differences in BPb were tenfold in our study, with males registering higher concentrations (Fig. 1). This discrepancy may not be upheld with a larger dataset, but we also cannot rule out the possibility that low BPbs observed among breeding-aged females could be attributed to mothers passing $\mathrm{Pb}$ body burdens off to their embryos. The presence of $\mathrm{BPb}$ and its ramifications for other species at Lake St Lucia have not been investigated. 
Such work is urgently needed especially given the longstanding severe drought in the region. Symptoms of physiological or nutritional stress may be exacerbated by ingested $\mathrm{Pb}$ in animals with lesser degrees of tolerance, and drought conditions have been shown to enhance the negative effects of heavy metals on wildlife (Rumbold et al. 2002). Future Nile crocodile research efforts in Africa would benefit from including BPb monitoring as part of standard protocol, especially in habitats where recreational fishing occurs.

\section{Acknowledgments}

We thank R. Taylor, P. Calverley, G. Champion, F. Myburgh, S. Kyle and family, the many volunteers who assisted with fieldwork, M. Dreslik for statistical guidance, Ezemvelo KwaZulu-Natal Widlife and the iSimangaliso Wetland Park Authority. The Ford Wildlife Foundation and the South African Water Research Commission are thanked for their vehicle/financial support.

\section{Compliance with ethical standards}

\section{Conflict of interest}

The authors declare that they have no conflict of interest.

\section{Informed Consent}

There were no human subjects, thus informed consent is not applicable for this study.

\section{Statement of Human and Animal Rights}

All applicable international, national, and/or institutional guidelines for the care and use of animals were followed. All procedures performed in studies involving animals were in accordance with the ethical standards of the institution or practice at which the studies were conducted. This article does not contain any studies with human participants performed by any of the authors.

\section{References}

Almi B, Mwase M, Sivertsen T, Musonda MM, Flaoyen A (2005) Hepatic and renal concentrations of 10 trace elements in crocodiles (Crocodylus niloticus) in Kafue and Luangwa Rivers in Zambia. Sci Total Environ 337:75-82

Botha H, van Hoven W, Guillette $\sqcup$ (2011) The decline of the Nile crocodile population in Loskop Dam, Olifants River, South Africa. Water SA 1:103-108

Botha AB, Haldorsen S, Porat N (2013) Geological history. In: Perissinotto R, Stretch DD, Taylor RH (eds) Ecology and conservation of estuarine ecosystems: Lake St Lucia as a global model. Cambridge University Press, Barcelona, pp 46-61

Brazaitis PJ (1968) The determination of sex in living crocodilians. Br J Herpetol 4:54-58 
Buekers J, Redeker ES, Smolder E (2009) Lead toxicity to wildlife: derivation of a critical blood concentration for wildlife monitoring based on literature data. Sci Total Environ 407:3431-3438

Burnham KP, Anderson DR (2002) Model selection and multimodel inference: a practical information-theoretic approach, 2nd edn. Springer, New York

Calverley PM, Downs CT (2014a) Population status of Nile crocodiles in Ndumo Game Reserve, KwaZulu-Natal, South Africa (1971-2012). Herpetologica 70:417-425

Calverley PM, Downs CT (2014b) Habitat use by Nile crocodiles in Ndumo Game Reserve, South Africa: a naturally patchy environment. Herpetologica 70:426-438

Campbell KR (2003) Ecotoxicology of crocodilians. Appl Herpetol 1:45-163

Camus AC, Mitchell MM, Williams JF, Jowett PLH (1998) Elevated lead levels in farmed American alligators Alligator mississippiensis consuming nutria Myocastor coypus meat contaminated by lead bullets. J World Aquac Soc 29:370-376

Chiasson RB (1962) Laboratory anatomy of the alligator. Wm C Brown Co, Dubuque

Combrink X (2014) Spatial and reproductive ecology and population status of the Nile Crocodile (Crocodylus niloticus) in the Lake St Lucia estuarine system, South Africa. Ph.D. thesis, University of KwaZulu-Natal, Pietermaritzburg, South Africa

Combrink X, Korrubel JL, Kyle R, Taylor R, Ross P (2011) Evidence of a declining Nile crocodile (Crocodylus niloticus) population at Lake Sibaya, South Africa. S Afr J Wildl Res 41:145-157

Combrink X, Warner JK, Hofmeyr M, Govender D, Ferreira SM (2012) Standard operating procedure for the monitoring, capture and sampling of Nile Crocodiles (Crocodylus niloticus). South African National Parks, Skukuza, South Africa, unpublished report, pp 1-14

Combrink X, Warner J, Taylor R, Downs CT (2013) Nile crocodiles. In: Perissinotto R, Stretch DD, Taylor RH (eds) Ecology and conservation of estuarine ecosystems: Lake St Lucia as a global model. Cambridge University Press, Barcelona, pp 333-353

Cook R, Behler J, Braezitis P, Dolensek E (1988) A survey of blood lead levels in crocodilians. In: Stoskopf MK (ed) International association for aquatic animal medicine proceedings, vol 19. W.B. Saunders, Philadelphia, pp 149-150

Ferreira SM, Pienaar D (2011) Degradation of the crocodile population in the Olifants River Gorge of Kruger National Park, South Africa. Aquat Conserv 21:155-164

Fisher IJ, Pain DJ, Thomas VG (2006) A review of lead poisoning from ammunition sources in terrestrial birds. Biol Conserv 131:421-432 
Franson JC (1996) Interpretation of tissue lead residues in birds other than waterfowl. In: Beyer WN, Heinz GH, Redmon-Norwood AW (eds) Environmental contaminants in wildlife: interpreting tissue concentrations. CRC Press, Boca Raton

Grillitsch B, Schiesari L (2010) The ecotoxicology of metals in reptiles. In: Sparling DW, Linder G, Bishop CA, Krest SK (eds) Ecotoxicology of reptiles and amphibians. CRC Press, New York

Hammerton KM, Jayasinghe N, Jeffree RA, Lim RP (2003) Experimental study of blood lead kinetics in estuarine crocodiles (Crocodylus porosus) exposed to ingested lead shot. Arch Environ Contam Toxicol 45:390-398

Heinz GH, Percival HF, Jenning ML (1991) Contaminants in America alligator eggs from Lake Apopka, Lake Griffin, and Lake Okeechobee, Florida. Environ Monit Assess 16:277-285

Jeffree RA, Markich SJ, Twining JR (2001) Element concentrations in the flesh and osteoderms of estuarine crocodiles (Crocodylus porosus) from the Alligator Rivers Region, northern Australia: biotic and geographic effects. Arch Environ Contam Toxicol 40:236-245

Kyle R (1999) Gillnetting in nature reserves: a case study from the Kosi Lakes, South Africa. Biol Conserv 88:183-192

Lambertucci SA, Donázar JA, Huertas AD, Jiménez B, Sáez M, Sanchez-Zapata JA, Hiraldo F (2011) Widening the problem of lead poisoning to a South American top scavenger: lead concentrations in feathers of wild Andean condors. Biol Conserv 144:1464-1471

Lance VA, Horn TR, Elsey RM, de Peyster A (2006) Chronic incidental lead ingestion in a group of captive-reared alligators (Alligator mississippiensis): possible contribution to reproductive failure. Comp Biochem Physiol C 142:30-35

Ma WC (1996) Lead in mammals. In: Beyer WN, Heinz GH, RedmonNorwood AW (eds) Environmental contaminants in wildlife: interpreting tissue concentrations. CRC Press, Boca Raton

Manolis SC, Webb GJW, Britton AR, Jeffree RA, Markich SJ (2002) Trace element concentrations of wild saltwater crocodile eggs. In: Makich SJ, Jefree RA (eds) The Finniss River, a natural laboratory of mining impacts - past, present and future. ANSTO, Sydney, pp 58-61

Marais J (2014) Crocodylus niloticus (Laurenti, 1768). In: Bates MF, Branch WR, Bauer AM, Burger M, Marais J, Alexander GJ, de Villiers (eds) Atlas and Red List of the Reptiles of South Africa, Lesotho and Swaziland. Suricata 1. South African National Biodiversity Institute, Pretoria

Milnes MR, Guillette LJ Jr (2008) Alligator tales: new lessons about environmental contaminants from a sentinel species. Bioscience 58:1027-1036

Myburgh JG, Kirberger RM, Steyl JCA, Soley JT, Booyse DG, Huchzermeyer FW, Lowers RH, Guillette $\sqcup$ (2014) The post-occipital spinal venous sinus of the Nile crocodile (Crocodylus 
niloticus): its anatomy and use for blood sample collection and intravenous infusions. J S Afr Vet Assoc 85:965. doi:10.4102/jsava.v85i1.965

Nadjafzadeh M, Hofer H, Krone O (2013) The link between feeding ecology and lead poisoning in white-tailed eagles. J Wildl Manag 77:48-57

Naidoo V, Wolter K, Espie I, Kotze A (2012) Lead toxicity: consequences and interventions in an intensively managed (Gyps coprotheres) vulture colony. J Zoo Wildl Med 43:573-578

Pain DJ (1996) Lead in waterfowl. In: Beyer WN, Heinz GH, Redmon-Norwood AW (eds) Environmental contaminants in wildlife: interpreting tissue concentrations. CRC Press, Boca Raton

Perkin-Elmer (1996) Analytical methods for atomic absorption spectroscopy. The PerkinElmer Corporation, p 300

Phelps RJ, Focardi S, Fossi C, Leonzio C, Renzoni A (1986) Chlorinated hydrocarbons and heavy metals in crocodile eggs from Zimbabwe. Trans Zimb Sci Assoc 63:8-15

R Development Core Team (2011) R: a language and environment for statistical computing. The R Foundation for Statistical Computing, Vienna, Austria. Available online at http://www.R-project.org/

Rainwater TR, Wu TH, Finger AG, Canas JE, Yu L, Reynolds KD, Coimbatore G, Barr B, Platt SG, Cobb GP, Anderson TA, McMurry ST (2007) Metals and organochlorine pesticides in caudal scutes of crocodiles from Belize and Costa Rica. Sci Total Environ 373:146-156

Rumbold DG, Fink LE, Laine KA, Niemezyk SL, Chandrasekhar T, Wankel SD, Kendall C (2002) Levels of mercury in alligators (Alligator mississippiensis) collected along a transect through the Florida Everglades. Sci Total Environ 297:239-252

Sparling DW, Linder G, Bishop CA, Krest SK (2010) Ecotoxicology of reptiles and amphibians. CRC Press, New York

Stretch D, Chrystal CP, Chrystal RA, Maine CM, Pringle JJ (2013) Estuary and lake hydrodynamics. In: Perissinotto R, Stretch DD, Taylor RH (eds) Ecology and conservation of estuarine ecosystems: Lake St Lucia as a global model. Cambridge University Press, Barcelona, pp 112-149

Swanepoel D, Boomker J, Kriek NPJ (2000) Selected chemical parameters in the blood and metals in the organs of the Nile crocodile Crocodylus niloticus, in the Kruger National Park. Onderstepoort J Vet Res 67:141-148

Thomas TG (1997) Attitudes and issues preventing bans on toxic lead shot and sinkers in North America and Europe. Environ Values 6:185-199 
Twinning JR, Markich SJ, Prince KE, Jeffree RA (1999) Osteoderms of estuarine crocodiles record their enhanced $\mathrm{Pb}$ exposure in Kakadu National Park. Envrion Sci Technol 33:43964400

Wallace KM, Leslie AJ (2008) Diet of the Nile crocodile (Crocodylus niloticus) in the Okavango Delta, Botswana. J Herpetol 42:361-368

Warner JK (2015) Morphometrics, ecotoxicology and stable isotope ecology of Nile crocodiles (Crocodylus niloticus) in KwaZulu-Natal, South Africa. Ph.D. thesis, University of KwaZulu-Natal, Pietermaritzburg, South Africa

Watson RT, Fuller M, Pokras M, Hunt WG (2009) Ingestion of Lead from Spent Ammunition: Implications for Wildlife and Humans. The Peregrine Fund, Boise

Xu Q, Fang S, Wang Z, Wang Z (2006) Heavy metal distribution in tissues and eggs of Chinese alligator (Alligator sinensis). Arch Environ Contam Toxicol 50:580-586

Zinterhofer LJM, Jatlow PI, Fappiano A (1971) Atomic absorption determination of lead in blood and urine in the presence of EDTA. J Lab Clin Med 78:664 